\title{
Effects of Precipitation Temperature on Nanoparticle Surface Area and Antibacterial Behaviour of $\mathrm{Mg}(\mathrm{OH})_{2}$ and MgO Nanoparticles
}

\author{
Banele Vatsha ${ }^{1,2}$, Phumlani Tetyana1, Poslet Morgan Shumbula ${ }^{1}$, Jane Catherine Ngila², \\ Lucky Mashudu Sikhwivhilu ${ }^{1}$, Richard Motlhaletsi Moutloali ${ }^{1}$ \\ ${ }^{1}$ Advanced Materials Division, DST/Mintek Nanotechnology Innovation Centre, Mintek, Randburg, South Africa; ${ }^{2}$ Department of \\ Applied Chemistry, University of Johannesburg, Doornfontein Campus, Johannesburg, South Africa. \\ Email: richardm@mintek.co.za
}

Received May $28^{\text {th }}, 2013$; revised June $29^{\text {th }}, 2013$; accepted July $15^{\text {th }}, 2013$

Copyright (C) 2013 Banele Vatsha et al. This is an open access article distributed under the Creative Commons Attribution License, which permits unrestricted use, distribution, and reproduction in any medium, provided the original work is properly cited.

\begin{abstract}
A series of $\mathrm{MgO}$ nanoparticles were prepared by first precipitating and isolating $\mathrm{Mg}(\mathrm{OH})_{2}$ nanoparticles from $\mathrm{Mg}\left(\mathrm{NO}_{3}\right)_{2}$ at three different temperatures using $\mathrm{NaOH}$ followed by their thermal decomposition also at three temperature settings. The effects of temperature at which precipitation and thermal decomposition of the hydroxide occurred were studied to assess their influence on nanoparticle size and surface area. The synthesised nanoparticles were characterized using a suite of techniques including Brunauer-Emmett-Teller (BET), X-ray diffraction (XRD), Transmission Electron Microscopy (TEM) and Scanning Electron Microscope (SEM) analysis. The average diameter range of $\mathrm{MgO}$ nanoparticles ranged between 15 and $35 \mathrm{~nm}$, while for the precursor $\mathrm{Mg}(\mathrm{OH})_{2}$ it varied between 28 and $45 \mathrm{~nm}$. The nanoparticle surface area obtained from BET studies was found in all cases to increase from 77 to $106.4 \mathrm{~m}^{2} / \mathrm{g}$ with increasing temperature of precipitation. Antibacterial activities of the prepared $\mathrm{Mg}(\mathrm{OH})_{2}$ and $\mathrm{MgO}$ nanoparticles were evaluated against the Gram-negative bacteria, Escherichia coli, and the Gram-positive bacteria, Staphylococcus aureus, using agar diffusion method. A correlation between surface area and antibacterial activity supported the mechanism of bacterial inactivation as the generation of reactive species. The $\mathrm{Mg}(\mathrm{OH})_{2}$ and $\mathrm{MgO}$ nanoparticles both exhibited pronounced bactericidal activity towards the Gram positive bacteria than Gram negative bacteria as indicated by the extend of the zone of inhibition around the nanoparticle.
\end{abstract}

Keywords: MgO; Nanoparticles; Precipitation; Crystallinity; Antibacterial

\section{Introduction}

The increased proliferation of infectious diseases due to microorganisms found in medical devices, food packaging, domestic appliances and water treatment systems has elicited increased attention [1-3]. In the recent years, extensive efforts have been made to develop new or improve known materials with antimicrobial properties. Specifically, increased resistance of microorganisms towards current biocides is of great concern specifically in people of compromised immune systems like the elderly, children and the sick. This has led to increased efforts to explore new types of antimicrobial agents. In particular, inorganic oxide nanomaterials like $\mathrm{CaO}, \mathrm{ZnO}$ and $\mathrm{MgO}$ have shown potential as effective alternatives in addressing some of these challenges [4-6]. For example, in the last decade literature exploring the use of metal ox- ides and specifically $\mathrm{MgO}$ has become widespread. These studies revealed that indeed $\mathrm{MgO}$ is able to deactivate both gram negative and gram positive bacteria and several mechanisms of deactivation postulated [4,7]. Relationship between particle size and activity was also reported. This has led to our interest in Mg based materials for applications in health and water [8].

Current research interest in inorganic nanomaterials synthesis has focused more on controlling and tailormaking materials into nanoparticles, nanorods, nanotubes, nanoplates, etc. with the aim of streamlining their applications and efficiency [6,9]. Moreover, investigations to develop versatile, cost effective and up-scalable methods in achieving predictable nanoparticle properties are paramount to the success of introducing these materials for widespread usage. These methods include sol-gel [10], 
hydrothermal [11], laser vaporization, chemical gas phase deposition and combustion aerosol synthesis [12]. However, in our investigations, there are drawbacks encountered from these conventional methods that tend to give lower yield, poor control of shape and size and use of corrosive chemicals. Indeed, it is generally known that $\mathrm{MgO}$ 's unique properties are related to the size of the nanoparticles [13]. Ouraipryvan et al. studied the synthesis of crystalline $\mathrm{MgO}$ nanoparticle with mesoporousassembled structure via a surfactant-modified sol-gel process [14]. The obtained results showed that the particle exhibited mesoporous structure and the diameter range was approximately 35 to $50 \mathrm{~nm}$. Continued search for control of nanoparticle synthesis using simple methods is still relevant.

In this study the precipitation method was adopted mainly because of its simplicity and relatively good control of the experimental conditions. The present study was carried out to investigate the effect of precipitation temperature on the morphology of $\mathrm{MgO}$ nanoparticles, specifically the surface area, and its influence on antibacterial (E. coli and S. aureus) activity. A strong correlation between nanoparticle surface area and antibacterial effects was observed giving an indirect way of establishing mechanism of bacterial inactivation.

\section{Experimental Section}

\subsection{Materials}

Magnesium nitrate $\left(\mathrm{Mg}\left(\mathrm{NO}_{3}\right)_{2}\right)$, sodium hydroxide $(\mathrm{NaOH})$ were purchased from Sigma Aldrich, South Africa. All solutions were prepared using freshly prepared high purity water from a Millipore unit, Q-POD. Escherichia coli (E. coli) and Staphylococcus aureus (S. aureus) strain were donated by Biolabels Unit at Mintek.

\subsection{Characterisation Techniques}

The XRD diffractograms were recorded on a Bruker D8 Advance X-ray diffractometer using a Co-K $\alpha(1.7902 \AA)$ monochromatic radiation source and a $\mathrm{Ni}$ filter with the operating voltage and current maintained at $40 \mathrm{kV}$ and 40 $\mathrm{mA}$ respectively in the $2 \theta$ range of $5^{\circ}-80^{\circ}$. The obtained diffraction patterns were processed using Eva software. Differential scanning calorimetric (DSC) analysis were performed using air as oxidant at the heating rate of $10^{\circ} \mathrm{C} \cdot \mathrm{min}^{-1}$ in a crimped aluminium crucible heated up to a temperature of $500^{\circ} \mathrm{C}$ using a Shimadzu DSC60 instrument with a TA60WS thermal analyser and FC60A controller. Scanning electron microspcopy (SEM) analyses were done on a Nova NanoSEM 200 from FEI operating at $10.0 \mathrm{KV}$. The Transmission Electron Microscopy (TEM) images were acquired on a Philips CM120 Biotwin Transmission Electron Microscope. The samples were prepared by placing a drop of a dilute sample on a carbon-coated copper grid (400 mesh, agar). The samples were allowed to dry completely at room temperature. Nitrogen adsorption measurements were performed at 77 $\mathrm{K}$ using a Micromeritics ASAP2010 system utilizing Brunauer Emmett-Teller (BET) calculations for surface area and $\mathrm{BJH}$ calculations for pore size distribution for the desorption branch of the isotherm.

\subsection{Synthesis and Characterisation of Magnesium Oxide Nanoparticles}

$\mathrm{Mg}\left(\mathrm{NO}_{3}\right)_{2}(0.2 \mathrm{M})$ and $\mathrm{NaOH}(0.4 \mathrm{M})$ solutions were prepared using deionized water from Millipore water purification system. Precipitation was induced by dropwise addition of $\mathrm{NaOH}$ into the $\mathrm{Mg}\left(\mathrm{NO}_{3}\right)_{2}$ solution under continuous stirring for 1 hour at different reaction temperatures $\left(\right.$ i.e. $23^{\circ} \mathrm{C}, 60^{\circ} \mathrm{C}$ and $85^{\circ} \mathrm{C}$ ) at $\mathrm{pH} 12$. The reaction mixture was cooled down to room temperature, centrifuged and washed with copious amount of high purity water and ethanol for effective removal of impurities. The final product was dried at $80^{\circ} \mathrm{C}$ for $24 \mathrm{~h}$ and calcined at different temperatures (i.e. $500^{\circ} \mathrm{C}, 600^{\circ} \mathrm{C}$ and $700^{\circ} \mathrm{C}$ ). Table 1 summarises the materials used and reaction conditions.

\subsection{Antibacterial Study Using Agar Diffusion Method}

Antibacterial activity was performed using agar diffusion method adopted from Sundrarajan et al., [13]. Bacterial cultures were grown overnight at $37^{\circ} \mathrm{C}$ by adding a single colony in $100 \mathrm{ml}$ Luria Bertani Broth. E. coli and $S$. aureus cultures $(0.1 \mathrm{ml}$ each) were plated out onto individual Nutrient Agar plates using the Aseptic technique. Holes/Wells were made on the nutrient agar inoculated with bacteria and (about $0.5 \mathrm{mg}$ ) $\mathrm{MgO}$ nanoparticle suspensions were decanted into the wells and the plates

Table 1. Precipitation and calcination temperatures used for MgO nanoparticle synthesis.

\begin{tabular}{cccc}
\hline Type & Sample & $\begin{array}{c}\text { Precipitation } \\
\text { temperature }\left({ }^{\circ} \mathrm{C}\right)\end{array}$ & $\begin{array}{c}\text { Calcination } \\
\text { temperature }\left({ }^{\circ} \mathrm{C}\right)\end{array}$ \\
\hline A & 1 & 23 & 500 \\
& 2 & 23 & 600 \\
& 3 & 23 & 700 \\
$\mathrm{~B}$ & 4 & 60 & 500 \\
& 5 & 60 & 600 \\
& 6 & 60 & 700 \\
$\mathrm{C}$ & 7 & 85 & 500 \\
& 9 & 85 & 600 \\
& 9 & 85 & 700 \\
\hline
\end{tabular}


incubated overnight at $37^{\circ} \mathrm{C}$. Finally, the diameters of zones of inhibition around the wells were measured against the control strain and measured with callipers. Zone of inhibition is the area in which the bacterial growth is stopped due to bacteriostatic effect of the compound and it measures the inhibitory effect of compound towards a particular microorganism.

\section{Results and Discussion}

\subsection{Preparation of $\mathrm{MgO}$ from $\mathrm{Mg}(\mathrm{OH})_{2}$ Nanoparticles}

The synthesis protocol employed for $\mathrm{MgO}$ nanoparticles was a precipitation-calcination method. This involved dropwise addition of sodium hydroxide into aqueous solution of magnesium nitrate at various temperatures between $25^{\circ} \mathrm{C}$ to $85^{\circ} \mathrm{C}$ to induce precipitation to form of magnesium hydroxide. In order to finally obtain $\mathrm{MgO}$ nanoparticles, the $\operatorname{Mg}(\mathrm{OH})_{2}$ powder was calcined at $500^{\circ} \mathrm{C}, 600^{\circ} \mathrm{C}$ and $700^{\circ} \mathrm{C}$ through the decomposition of $\mathrm{Mg}(\mathrm{OH})_{2}$ to $\mathrm{MgO}$ nanoparticles (Scheme 1).

Temperature of precipitation is one method of manipulating nanoparticle size and morphology. For example, Yildirim and Duncan observed that the size of spherical $\mathrm{ZnO}$ nanoparticles could be manipulated by the choice of precipitation temperature $(13.0 \pm 1.9 \mathrm{~nm}$ at $25^{\circ} \mathrm{C}$ and $9.0 \pm 1.3 \mathrm{~nm}$ at $80^{\circ} \mathrm{C}$ ), which they attributed to changes in the nature of adsorption events between $\mathrm{ZnO}$ crystals and organic molecules used as surfactants [15]. Even though, no surfactants were used in the current method, good control and manipulation of nanoparticle morphologies were obtained by varying the precipitation temperature. This indicates that precipitation temperature might be an important factor in controlling morphologies in instances of ionic effects rather surfactants are being used. This will assist in lowering the overall cost associated with controlled nanoparticle synthesis. It is however important to note that many methods and their variants have been used to produce $\mathrm{MgO}$ nanoparticles [16-24].

\subsection{Thermal Analysis of the $\mathrm{Mg}(\mathrm{OH})_{2}$ Transformation to $\mathrm{MgO}$}

Figure 1 shows the DSC and TGA profiles of the decomposition and transformation of $\mathrm{Mg}(\mathrm{OH})_{2}$ nanoparticles into $\mathrm{MgO}$ nanoparticles. The thermograms are do-

$$
\begin{aligned}
& \text { Phase I } \mathrm{Mg}\left(\mathrm{NO}_{3}\right)_{2(\text { aq) }}+2 \mathrm{NaOH}_{(\text {aq) }} \frac{1) \text { Precipitation }}{23,60,85^{\circ} \mathrm{C}} \mathrm{Mg}(\mathrm{OH})_{2(\mathrm{~s})}+2 \mathrm{NaNO}_{3(\text { aq })} \\
& \text { Phase II } \quad \mathrm{Mg}(\mathrm{OH})_{2(\mathrm{~s})} \frac{\text { 2) Calcination }}{500,600,700^{\circ} \mathrm{C}} \mathrm{MgO}_{(\mathrm{s})}
\end{aligned}
$$

Scheme 1. MgO derived from $\mathrm{Mg}\left(\mathrm{NO}_{3}\right)_{2}$ precursor reaction mechanism through the $\mathrm{Mg}(\mathrm{OH})_{2}$ intermediate.

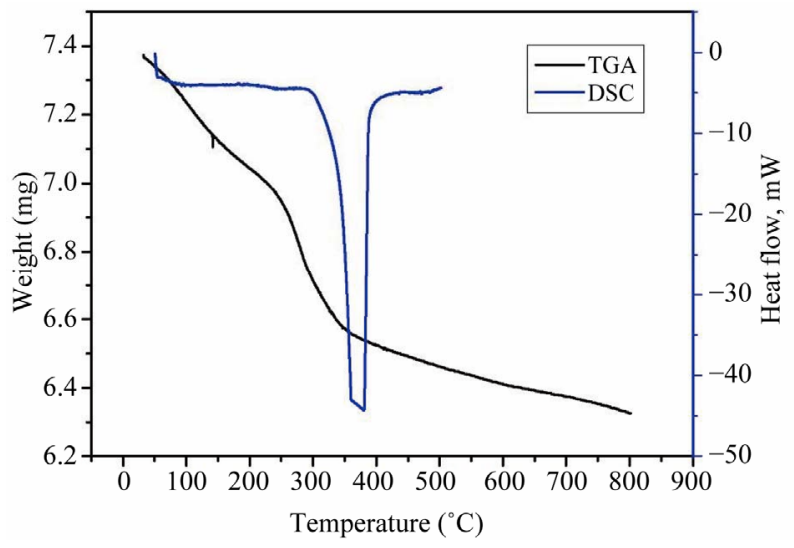

Figure 1. TGA and DSC profiles of the decomposition of the prepared $\mathrm{Mg}(\mathrm{OH})_{2}$ to $\mathrm{MgO}$ nanoparticles.

minated by one major thermal event centred on $380^{\circ} \mathrm{C}$ (DSC) with an onset at $250^{\circ} \mathrm{C}$ (TGA) or $280^{\circ} \mathrm{C}$ (DSC). This onset marks the start of the decomposition of $\mathrm{Mg}(\mathrm{OH})_{2}$ to $\mathrm{MgO}$ nanoparticles which occurs typically during calcination of the hydroxide material $[11,18$, 25-27]. Other thermal events observed were in the temperature regions around $100^{\circ} \mathrm{C}, 240^{\circ} \mathrm{C}$ and $465^{\circ} \mathrm{C}$. The first event at $100^{\circ} \mathrm{C}$ is probably related to the loss of physically adsorbed or unbound water molecules on the hydroxide. The thermal event around $240^{\circ} \mathrm{C}$ is generally attributed to the loss of chemisorbed water molecules [28]. The thermal event at $465^{\circ} \mathrm{C}$ that occurs after the transformation of the hydroxide to the oxide is associated with the phase transformation of amorphous $\mathrm{MgO}$ into its cubic ordered phase [27]. This event, however, is not widely reported or observed in literature during thermal transformation of $\mathrm{Mg}(\mathrm{OH})_{2}$ to $\mathrm{MgO}$.

\subsection{X-Ray Characterisation of $\operatorname{Mg}(\mathrm{OH})_{2}$ and MgO Nanoparticles}

Figure 2 depicts the X-ray diffractogram of $\mathrm{Mg}(\mathrm{OH})_{2}$ nanoparticles precipitated at different temperatures, viz. A at $23^{\circ} \mathrm{C}, \mathrm{B}$ at $60^{\circ} \mathrm{C}$ and $\mathrm{C}$ at $85^{\circ} \mathrm{C}$. The three diffractograms are similar and exhibit the same diffraction pattern associated with $\operatorname{Mg}(\mathrm{OH})_{2}$ materials. The multiple diffraction peaks from $\mathrm{Mg}(\mathrm{OH})_{2}$ at $22^{\circ}, 44^{\circ}, 60^{\circ}, 69^{\circ}, 74^{\circ}$, $82^{\circ}$ and $86^{\circ}$ arise from the $001,100,011,012,110,200$ and 021 planes respectively according to a report by Sundrarajan et al. [13] and the XRD PDF2010: 000021169. This confirmed that the formation of pure $\operatorname{Mg}(\mathrm{OH})_{2}$ nanoparticles is indifferent to the precipitation temperature used.

Figure 3 is the $\mathrm{X}$-ray diffractograms of $\mathrm{MgO}$ nanoparticles produced by calcining $\mathrm{Mg}(\mathrm{OH})_{2}$ at different temperatures. The nanoparticles produced by calcination at $500^{\circ} \mathrm{C}(\mathrm{A}), 600^{\circ} \mathrm{C}(\mathrm{B})$ and $700^{\circ} \mathrm{C}(\mathrm{C})$ all exhibited identical diffraction patterns. The samples all had diffraction 


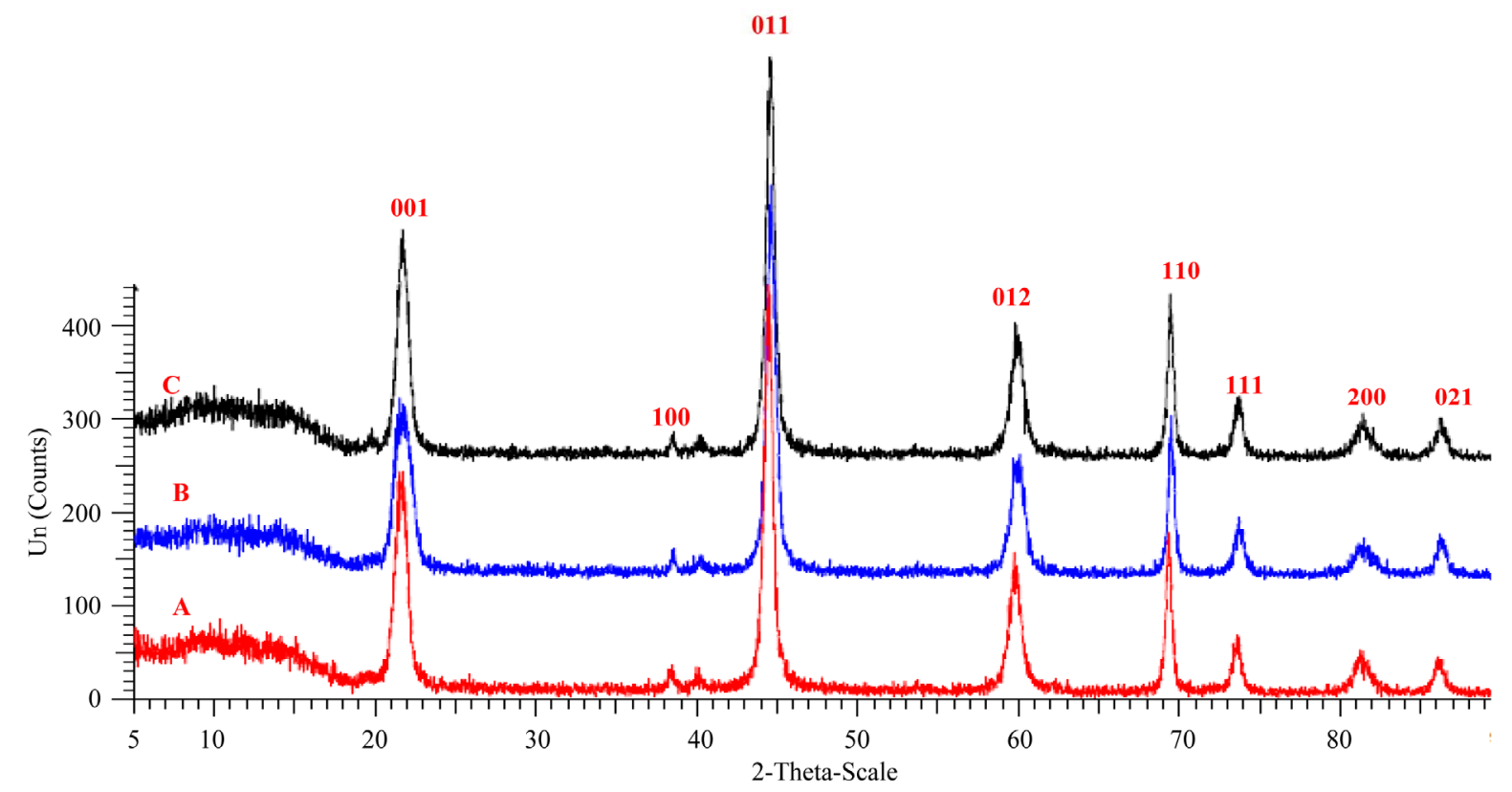

Figure 2. Comparison of X-ray diffractograms of $\mathrm{Mg}(\mathrm{OH})_{2}$ nanoparticles precipitated at $23^{\circ} \mathrm{C}(\mathrm{A}), 60^{\circ} \mathrm{C}(\mathrm{B})$ and $85^{\circ} \mathrm{C}(\mathrm{C})$.

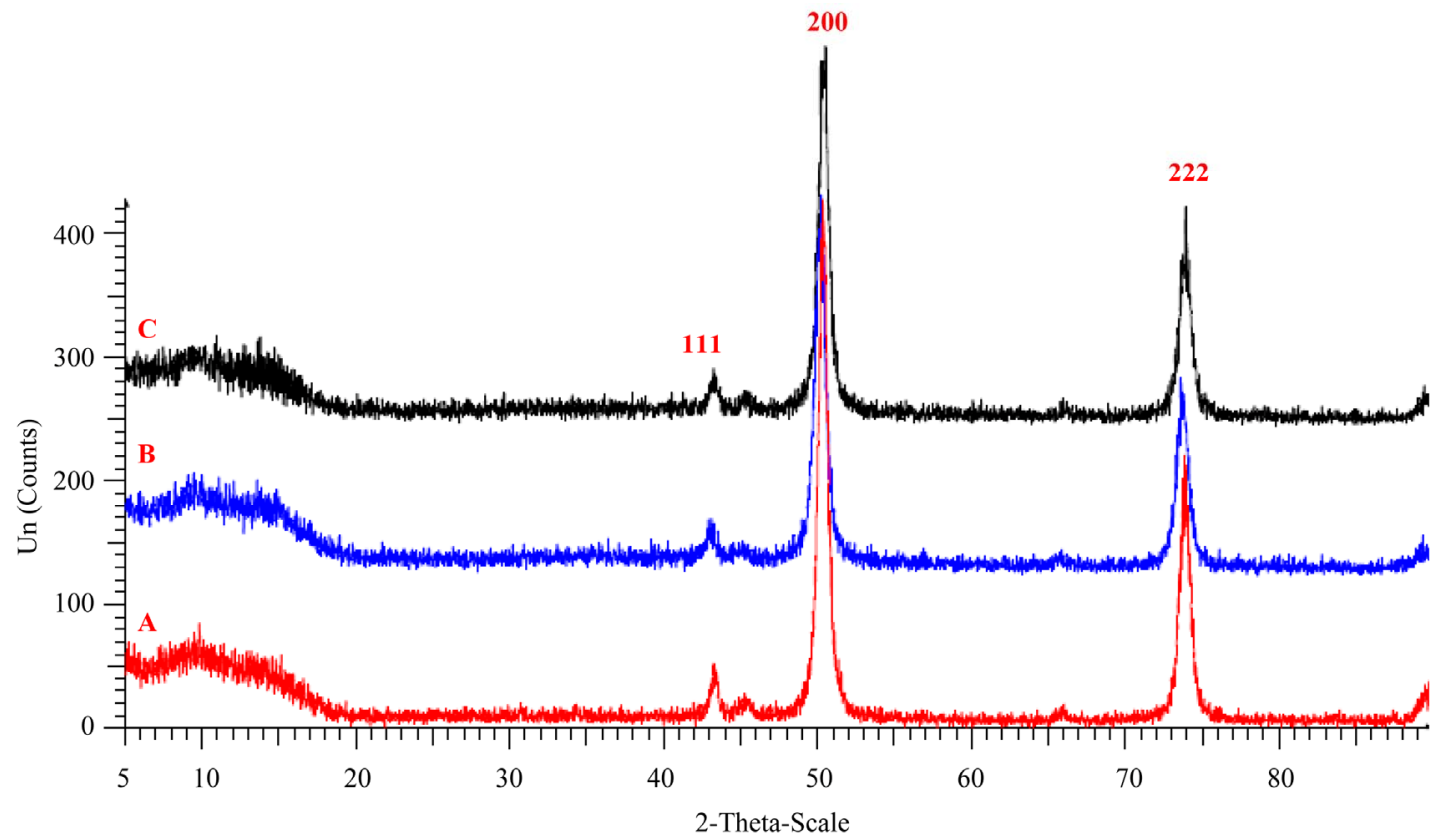

Figure 3. X-ray diffractograms of $\mathrm{MgO}$ particles prepared from $\mathrm{Mg}(\mathrm{OH})_{2}$ precipitated at $23^{\circ} \mathrm{C}(\mathrm{A}), 60^{\circ} \mathrm{C}(\mathrm{B})$ and $85^{\circ} \mathrm{C}(\mathrm{C})$.

peaks at $44^{\circ}, 50^{\circ}$ and $74^{\circ}$ are assigned to 111,200 and 222 planes respectively (XRD PDF2010:000021207). This clearly indicated that $\mathrm{Mg}(\mathrm{OH})_{2}$ was completely transformed to crystalline $\mathrm{MgO}$ with no traces of impurities observed. The results also show that calcining at the relatively low temperature of $500^{\circ} \mathrm{C}$ is adequate to produce pure $\mathrm{MgO}$ using this method. The crystallite sizes (Table 2) were also calculated on the samples using 111, 200 and 220 diffraction maxima from the half-width of diffraction peaks using Scherrer's equation. The calculated crystallite sizes are comparable (on the lower end) with the sizes obtained from TEM analysis for $\mathrm{MgO}$ nanoparticles. According to the XRD data, the mean crystallite sizes of the $\mathrm{MgO}$ nanoparticles were calculated by using the Debye Scherrer formula.

$$
D=\frac{0.9 \lambda}{\beta \cos \theta}
$$


Table 2. BET results of MgO nanoparticles calcined at $700^{\circ} \mathrm{C}$.

\begin{tabular}{ccccc}
\hline $\begin{array}{c}\text { Sample name } \\
\text { (precipitation }\end{array}$ & \multirow{2}{*}{$\begin{array}{c}\text { Surface area } \\
\left(\mathrm{m}^{2} / \mathrm{g}\right)\end{array}$} & \multicolumn{3}{c}{ XRD crystallite sizes $(\mathrm{nm})$} \\
\cline { 3 - 5 } temperature $)$ & 77.6 & 18.5 & 18.8 & 17.5 \\
\hline $\mathrm{Mg}(\mathrm{OH})_{2}\left(23^{\circ} \mathrm{C}\right)$ & $77.6)$ & $(200)$ & $(220)$ \\
$\mathrm{Mg}(\mathrm{OH})_{2}\left(60^{\circ} \mathrm{C}\right)$ & 88.1 & 10.7 & 15.3 & 15.3 \\
$\mathrm{Mg}(\mathrm{OH})_{2}\left(85^{\circ} \mathrm{C}\right)$ & 106.4 & 13.7 & 16.3 & 15.0 \\
\hline
\end{tabular}

where $\lambda=$ cobalt wavelength $(1.7902 \AA), \theta$ is the bragg diffraction angle of the XRD peak, $\beta$ is the measured broadening of the diffraction line peak at an angle $2 \theta$, at half its maximum intensity (FWHM) in radian.

\subsection{BET Analysis of $\mathrm{Mg}(\mathrm{OH})_{2}$ and $\mathrm{MgO}$ Nanoparticles}

The BET method was used to obtain specific surface area for the $\mathrm{MgO}$ nanoparticles. BJH analysis was used to determine the pore size distribution. This indicated that $\mathrm{MgO}$ nanoparticles exhibit a bimodal pore distribution which contains mesopores of between $1.7-5.2 \mathrm{~nm}$ and larger mesopores with pore size averaging at $34.0 \mathrm{~nm}$. Rezaei et al. observed that the specific surface area of the nanoparticles increased with increasing refluxing time and temperature [29]. This is in line with our results that showed that nanoparticles produced at different precipitation temperature showed that the specific surface area increased with an increase in precipitation temperature (Table 2).

\subsection{TEM Analysis of $\mathrm{Mg}(\mathrm{OH})_{2}$ and $\mathrm{MgO}$ Nanoparticles}

TEM was used to analyse $\mathrm{Mg}(\mathrm{OH})_{2}$ nanoparticles precipitated at different temperatures. The general observation was that the shapes appear to be different (Figure 4). It would be interesting to interrogate this observation further but due to no access to a TEM instrument with higher resolution, this idea was not explored further. The average size distribution of the nanoparticles is shown in Figure 4 with a mean of $37 \mathrm{~nm}$ for $\mathrm{Mg}(\mathrm{OH})_{2}$ precipitated at $25^{\circ} \mathrm{C}$ (Figure $\left.4(\mathbf{a})\right), 28 \mathrm{~nm}$ for those produced at $60^{\circ} \mathrm{C}$ (Figure $4(\mathbf{b})$ ) and $45 \mathrm{~nm}$ for those precipitated at $85^{\circ} \mathrm{C}$ (Figure 4(c)). Literature shows that precipitation temperature has an influence on the shapes and not size, with flakes being observed when lower temperatures are used $[13,30,31]$. Others have recently reported that there is a correlation between precipitation temperature and final particle size as long as the reaction is allowed to progress for longer periods at lower temperatures to allow complete reaction and other processes to take place [32]. This aspect however widely reported, gives conflicting conclusions in literature to result in one predictive approach.
In the current work indications are that the size variance does not show an obvious relationship with the precipitation temperature used an observation that was also made by Lv et al. [33].

$\mathrm{MgO}$ nanoparticles prepared by calcination of $\mathrm{Mg}(\mathrm{OH})_{2}$ materials at different temperatures, viz. 500, 600 and $700^{\circ} \mathrm{C}$ were also characterised using TEM. The overall average size range determined by TEM analysis results ranged from 14 to $32 \mathrm{~nm}$ (Table 3). The average size of nanoparticles obtained at 500 and $600^{\circ} \mathrm{C}$ were comparable irespective of the precipitation temperature used to produce $\mathrm{Mg}(\mathrm{OH})_{2}$ particles with a narrow distribution between 14 and $20 \mathrm{~nm}$. On the other hand, nanoparticles obtained at $700^{\circ} \mathrm{C}$ were relatively larger (between 27 and $32 \mathrm{~nm}$ ). Even though the general observation was that all calcination temperatures resulted in average sizes of less than $35 \mathrm{~nm}$, the general appearance of the nanoparticles seemed different. Sundrarajan et al. also observed the effects temperature had on the morphology of $\mathrm{MgO}$ nanoparticles where the initial flakes were transformed as the calcination temperature was increased [13]. In so far as the precipitation temperature was concerned, it was observed that nanoparticles precipitated at higher temperature $\left(85^{\circ} \mathrm{C}\right)$ exhibited more defined shapes compared to those obtained at $23^{\circ} \mathrm{C}$ and $60^{\circ} \mathrm{C}$, indicating that nanoparticle shape and size might be influenced by the precipitation temperature of the precursor $\mathrm{Mg}(\mathrm{OH})_{2}$ powder was produced. Mageshwari and Sathyamoorthy used a precipitation temperature of $100^{\circ} \mathrm{C}$ to produce $\mathrm{MgO}$ nanoparticles with a $5 \mathrm{~nm}$ average, an observation that indicates that other parameters are more important at controlling particle size than precipitation temperature [34].

\subsection{Antibacterial Studies}

The antibacterial effects of $\mathrm{Mg}(\mathrm{OH})_{2}$ and $\mathrm{MgO}$ nanoparticles were investigated using gram negative and gram positive bacterial strains, E. coli and S. aureus respectively, by the well diffusion agar method. The zones of inhibition, the clearing zones around the wells without visible bacterial growth, were measured from three separate plates and are captured in Figure 5. These zones indicate the antibacterial activity of $\mathrm{Mg}(\mathrm{OH})_{2}$ and $\mathrm{MgO}$ since no bacterial growth is observed in those areas. The antibacterial activity, from both $\mathrm{Mg}(\mathrm{OH})_{2}$ and $\mathrm{MgO}$, was higher in $S$. aureus than that observed in E. coli tests, This can be attributed in part to the general observation that gram positive bacterial strains are more susceptible to antibacterial materials as compared to gram negative strains due to differences in their cell wall structure [35]. On the other hand, $\mathrm{MgO}$ exhibited consistently higher activity against $S$. aureus bacteria than $\mathrm{Mg}(\mathrm{OH})_{2}$ (Figure 5). This is in line with literature observation by Panacek et al. [36] and Pan et al. [37] that smaller nanoparticles 

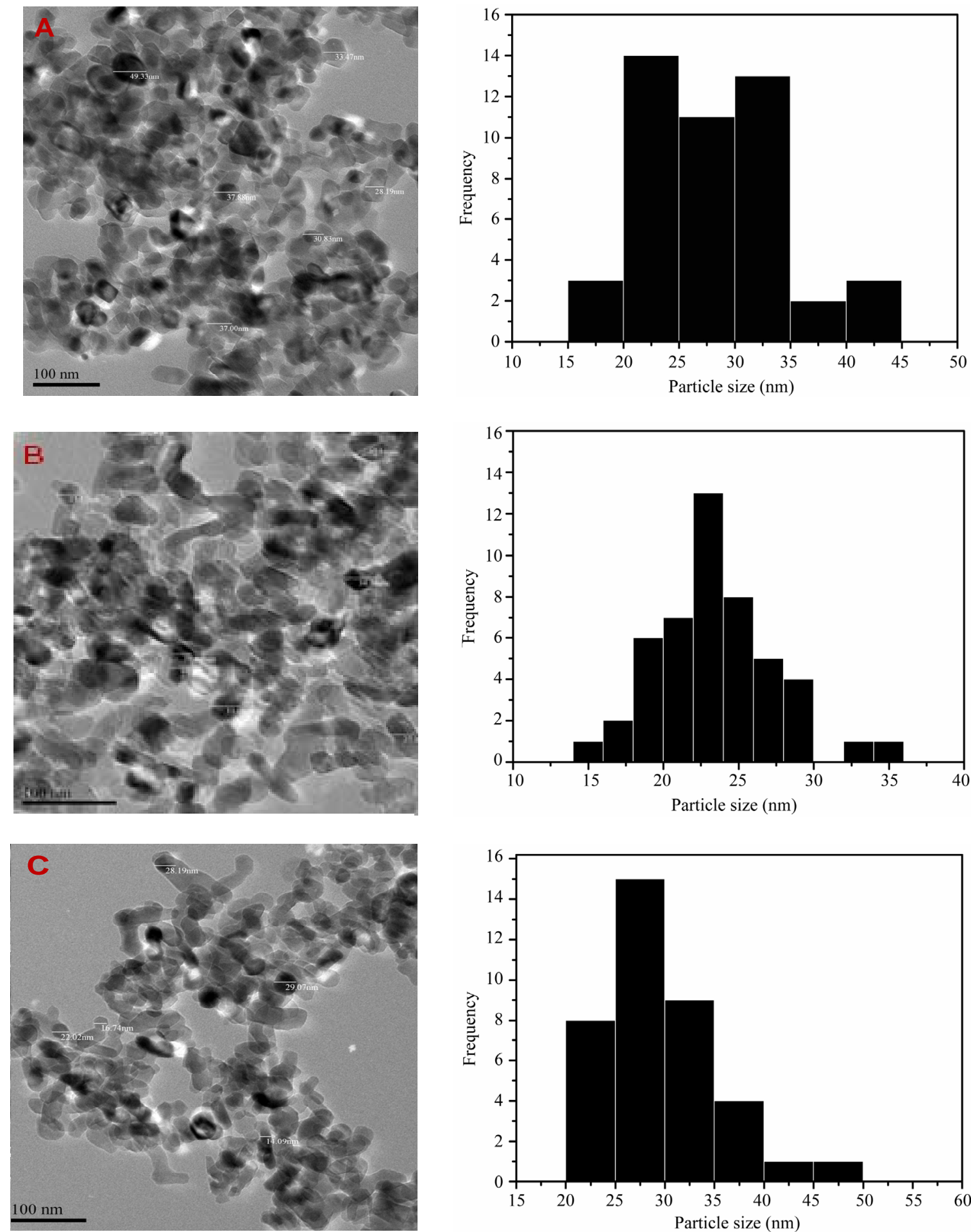

Figure 4. TEM micrographs of $\mathrm{MgO}$ nanoparticles calcined at $700^{\circ} \mathrm{C}(\mathrm{C})$ from $\mathrm{Mg}(\mathrm{OH})_{2}$ precipitated $23^{\circ} \mathrm{C}(\mathrm{A}), 60^{\circ} \mathrm{C}(\mathrm{B})$, $85^{\circ} \mathrm{C}(\mathrm{C})$ and with their respective histograms generated from the TEM micrographs.

are more active than larger ones and thus $\mathrm{MgO}$ nanoparticles, which are smaller than $\mathrm{Mg}(\mathrm{OH})_{2}$ nanoparticles, are more effective towards inhibition of bacterial growth. The mechanism of bacterial inhibition for nanoparticle is usually attributed to the generation of reactive radicals [38]. This mechanism is also assumed in this study and therefore the different antibacterial activities of the materials are related to their ability to generate such radicals, 

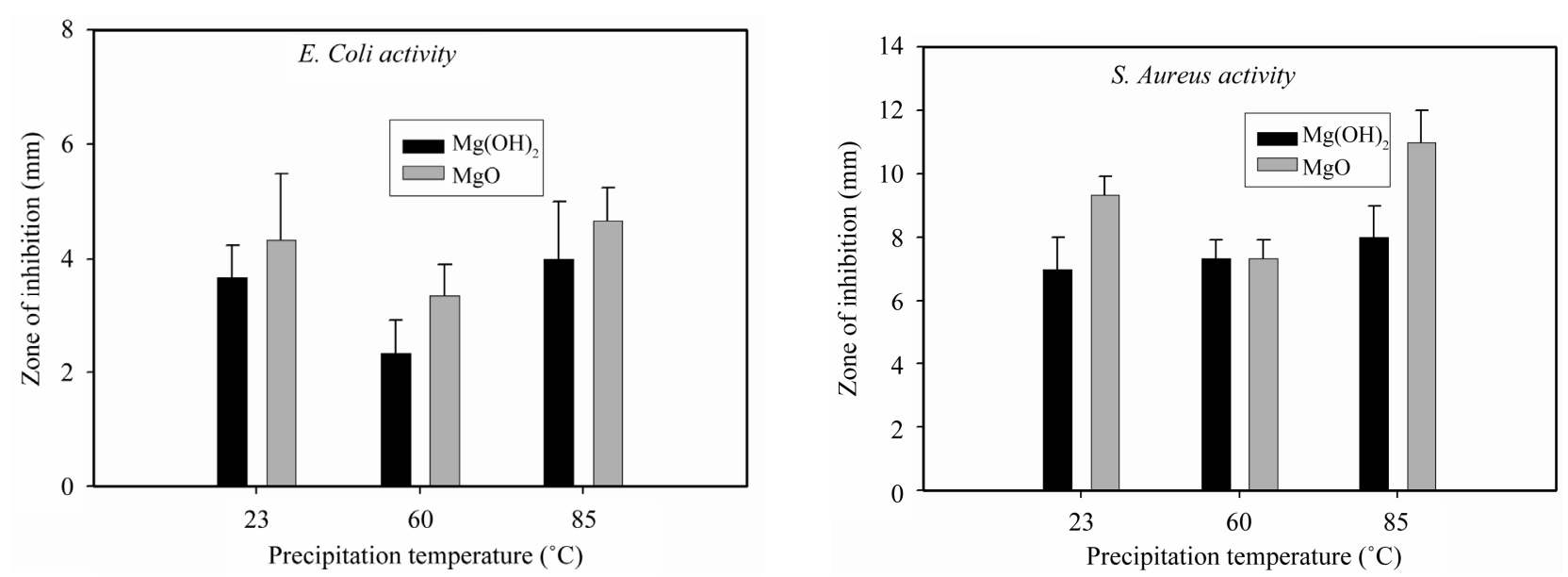

Figure 5. Antibacterial activities of $\mathrm{Mg}(\mathrm{OH})_{2}$ and $\mathrm{MgO}$ as measured by zone of inhibition method.

Table 3. Summary of preparation conditions and average nanoparticle sizes $(\mathbf{n m})$.

\begin{tabular}{cccccc}
\hline $\begin{array}{c}\text { Precipitation } \\
\text { temperature } \\
\left({ }^{\circ} \mathrm{C}\right)\end{array}$ & $\begin{array}{c}\text { Calcination } \\
\text { temperature } \\
\left({ }^{\circ} \mathrm{C}\right)\end{array}$ & 500 & 600 & 700 & $\mathrm{Mg}(\mathrm{OH})_{2}$ \\
\hline 25 & 15 & 14 & 27 & 37 \\
60 & 16 & 18 & 23 & 28 \\
& 18 & 20 & 32 & 45 \\
\hline
\end{tabular}

a property that is dependent on the surface area and crystal edges exposed. It is known that the higher the surface area per unit mass, the more reactive material becomes. The density of radicals produced, and hence the inhibition ability is directly related to this property and hence the trends observed in this study (Table 4). For example, $\mathrm{MgO}$ is known to be more reactive than its hydroxide and hence the activity trend observed whereby the oxide is more active than the analogous hydroxide in all cases studied. Within the materials themselves, e.g. oxides, the activity trend follows the surface area and nanoparticle size trend established in prior sections.

\section{Conclusion}

Synthesis and antibacterial effects of $\mathrm{Mg}(\mathrm{OH})_{2}$ and $\mathrm{MgO}$ nanoparticles were undertaken and factors contributing to the formation of well-defined nanoparticles were explored. Temperature at which calcination of $\mathrm{Mg}(\mathrm{OH})_{2}$ to $\mathrm{MgO}$ was performed was found to be more important than the temperature at which $\mathrm{Mg}(\mathrm{OH})_{2}$ was synthesised in determining the final $\mathrm{MgO}$ nanoparticle size. A simple and cost effective method to obtain nanoparticles with narrow size dispersion was established in this study. The antibacterial activities of the prepared $\mathrm{Mg}(\mathrm{OH})_{2}$ and $\mathrm{MgO}$ nanoparticles were studied using well-diffusion method. Both these nanoparticle types exhibited greater
Table 4. Relationship of $\mathrm{MgO}$ (calcined at $700^{\circ} \mathrm{C}$ ) antibacterial activity towards $S$. aureus and surface area.

\begin{tabular}{ccccccc}
\hline \multirow{2}{*}{$\begin{array}{c}\text { Precipitation } \\
\text { temperature }\end{array}$} & $\begin{array}{c}\text { Activity against } \\
\text { S. aureus }(\mathrm{mm})\end{array}$ & $\begin{array}{c}\text { Surface } \\
\text { area } \\
\mathrm{Mg}(\mathrm{OH})_{2}\end{array}$ & $\mathrm{MgO}$ & $\begin{array}{c}\mathrm{MgO} \\
(\mathrm{nm})\end{array}$ & $\begin{array}{c}\mathrm{Mg}(\mathrm{OH})_{2} \\
(\mathrm{~nm})\end{array}$ \\
\cline { 2 - 4 } 23 & 6.5 & 8.6 & 77.6 & 27 & 37 \\
60 & 6.8 & 7.0 & 88.1 & 23 & 28 \\
85 & 7.5 & 10.2 & 104.2 & 32 & 45 \\
\hline
\end{tabular}

antibacterial effects towards Gram-positive bacteria than Gram-negative ones. In all cases, the antibacterial activity of $\mathrm{Mg}(\mathrm{OH})_{2}$ was lower than that of $\mathrm{MgO}$, i.e. against both $E$. coli and $S$. aureus. The antibacterial activity was closely related to the surface area than to the actual nanoparticle size observed. The relatively low cost and abundance of $\mathrm{Mg}$ based nanoparticles $\left(\mathrm{Mg}(\mathrm{OH})_{2}\right.$ and $\left.\mathrm{MgO}\right)$ versus other metal based antibacterial agents make this material a viable alternative for this application, i.e. E. coli and S. aureus inhibition.

\section{REFERENCES}

[1] D. Lee, R. E. Cohen and M. F. Rubner, "Antibacterial Properties of Ag Nanoparticle Loaded Multilayers and Formation of Magnetically Directed Antibacterial Microparticles," Langmuir, Vol. 21, No. 21, 2005, pp. 96519659. http://dx.doi.org/10.1021/la0513306

[2] L.-A. B. Rawlinson, S. A. M. Ryan, G. Mantovani, J. A. Syrett, D. M. Haddleton and D. J. Brayden, "Antibacterial Effects of Poly(2-(Dimethylamino Ethyl)Methacrylate) against Selected Gram-Positive and Gram-Negative Bacteria," Biomacromolecules, Vol. 11, No. 2, 2009, pp. 443453. http://dx.doi.org/10.1021/bm901166y

[3] M. Fernandez-Garcia and A. Munoz-Bonilla, "Polymeric Materials with Antimicrobial Activity," Progress in Polymer Science, Vol. 37, No. 2, 2012, pp. 281-339. 
http://dx.doi.org/10.1016/j.progpolymsci.2011.08.005

[4] P. K. Stoimenov, R. L. Klinger, G. L. Marchin and K. J. Klabunde, "Metal Oxide Nanoparticles as Bactericidal Agents," Langmuir, Vol. 18, No. 17, 2002, pp. 6679-6686. http://dx.doi.org/10.1021/la0202374

[5] A. G. Nasibulin, L. Sun, S. HaaMaaLaInen, S. D. Shandakov, F. Banhart and E. I. Kauppinen, "In Situ TEM Observation of $\mathrm{MgO}$ Nanorod Growth," Crystal Growth \& Design, Vol. 10, No. 1, 2009, pp. 414-417. http://dx.doi.org/10.1021/cg9010168

[6] Y. G. Zhang, H. Y. He and B. C. Pan, "Structural Features and Electronic Properties of $\mathrm{MgO}$ Nanosheets and Nanobelts," The Journal of Physical Chemistry C, Vol. 116, No. 43, 2012, pp. 23130-23135. http://dx.doi.org/10.1021/jp3077062

[7] K. Krishnamoorthy, J. Y. Moon, H. B. Hyun, S. K. Cho and S. J. Kim, "Mechanistic Investigation on the Toxicity of MgO Nanoparticles toward Cancer Cells," Journal of Materials Chemistry, Vol. 22, No. 47, 2012, pp. 2461024617. http://dx.doi.org/10.1039/c2jm35087d

[8] L. Bertinetti, C. Drouet, C. Combes, C. Rey, A. Tampieri, S. Coluccia and G. Martra, "Surface Characteristics of Nanocrystalline Apatites: Effect of Mg Surface Enrichment on Morphology, Surface Hydration Species, and Cationic Environments," Langmuir, Vol. 25, No. 10, 2009, pp. 5647-5654. http://dx.doi.org/10.1021/la804230j

[9] A. Sternig, S. Klacar, J. Bernardi, M. StoGer-Pollach, H. GroNbeck and O. Diwald, "Phase Separation at the Nanoscale: Structural Properties of $\mathrm{BaO}$ Segregates on $\mathrm{MgO}$ Based Nanoparticles," The Journal of Physical Chemistry C, Vol. 115, No. 32, 2011, pp. 15853-15861. http://dx.doi.org/10.1021/jp204043g

[10] V. M. Boddu, S. Dabir, Y. Viswanath and S. W. Maloney, "Synthesis and Characterization of Coralline Magnesium Oxide Nanoparticles," Journal of American Ceramic Society, Vol. 91, No. 5, 2008, pp. 1718-1720. http://dx.doi.org/10.1111/j.1551-2916.2008.02344.x

[11] G. Wang, L. Zhang, H. Dai, J. Deng, C. Liu, H. He and C. T. Au, "Assisted Hydrothermal Synthesis and Characterization of Rectangular Parallelepiped and Hexagonal Prism Single-Crystalline $\mathrm{MgO}$ with Three-Dimensional Wormhole Like Mesopores," Inorganic Chemistry, Vol. 47, No. 10, 2008, pp. 4015-4022. http://dx.doi.org/10.1021/ic7015462

[12] J. C. Yu, A. Xu, L. Zhang, R. Song and L. Wu, "Synthesis and Characterization of Porous Magnesium Hydroxide and Oxide Nanoplates," Journal of Physical Chemistry B, Vol. 108, No. 1, 2004, pp. 64-70. http://dx.doi.org/10.1021/jp035340w

[13] S. Sundarrajan and S. Ramakrishna, "Fabrication of Nanocomposite Membranes from Nanofibers and Nanoparticles for Protection against Chemical Warfare Stimulants," Journal of Materials Science, Vol. 42, No. 20, 2007, pp. 8400-8407. http://dx.doi.org/10.1007/s10853-007-1786-4

[14] P. Ouraipryvan, T. Sreethawong and S. Chavadej, "Synthesis of Crystalline $\mathrm{MgO}$ Nanoparticle with Mesoporous-Assembled Structure via a Surfactant-Modified SolGel Process," Materials Letters, Vol. 63, No. 21, 2009, pp. 1862-1865.

[15] O. A. Yıldırım and C. Duncan, "Effect of Precipitation Temperature and Organic Additives on Size and Morphology of ZnO Nanoparticles," Journal of Materials Research, Vol. 27, No. 11, 2012, pp. 1452-1461. http://dx.doi.org/10.1557/jmr.2012.58

[16] H. C. Bajaj, I. Mukhopadhyay and A. B. Panda, "Controlled Synthesis of Different Morphologies of $\mathrm{MgO}$ and Their Use as Solid Base Catalysts," Journal of Physical Chemistry C, Vol. 115, No. 25, 2011, pp. 12308-12316. http://dx.doi.org/10.1021/jp2022314

[17] N. Budiredla, A. Kumar, S. Thota and J. Kumar, "Synthesis and Optical Characterization of $\mathrm{Mg}_{1-\mathrm{x}} \mathrm{Ni}_{\mathrm{x}} \mathrm{O}$ Nanostructures," ISRNetwork Nanomaterials, Vol. 2012, 2012, Article ID: 865373.

[18] X. L. Cao, C. Cheng, Y. L. Ma and C. S. Zhao, "Preparation of Silver Nanoparticles with Antimicrobial Activities and the Researches of Their Biocompatibilities," Journal of Materials Science, Vol. 21, No. 10, 2010, pp. 28612868.

[19] P. P. Fedorov, E. A. Tkachenko, S. V. Kuznetsov, V. V. Voronov and S. V. Lavrishchev, "Preparation of $\mathrm{MgO}$ Nanoparticles," Inorganic Materials, Vol. 43, No. 5, 2007, pp. 502-504. http://dx.doi.org/10.1134/S0020168507050111

[20] M. Haertelt, A. Fielicke, G. Meijer, K. Kwapien, M. Sierka and J. Sauer, "Structure Determination of Neutral MgO Clusters-Hexagonal Nanotubes and Cages," Physical Chemistry Chemical Physics, Vol. 14, No. 8, 2012, pp. 2849-2856. http://dx.doi.org/10.1039/c2cp23432g

[21] J. Hu, Z. Song, L. Chen, H. Yang, J. Li and R. Richards, "Adsorption Properties of MgO (111) Nanoplates for the Dye Pollutants from Wastewater," Journal of Chemical Engineering Data, Vol. 55, No. 9, 2010, pp. 3742-3748. http://dx.doi.org/10.1021/je100274e

[22] F. Khairallah and A. Glisenti, "Synthesis, Characterization and Reactivity Study of Nanoscale Magnesium Oxide," Journal of Molecular Catalysis A: Chemical, Vol. 274, No. 1-2, 2007, pp. 137-147. http://dx.doi.org/10.1016/j.molcata.2007.04.039

[23] A. O. Menezes, P. S. Silva, E. P. Hernandez, L. E. P. Borges and M. A. Fraga, "Tuning Surface Basic Properties of Nanocrystalline $\mathrm{MgO}$ by Controlling the Preparation Conditions," Langmuir, Vol. 26, No. 5, 2010, pp. 3382-3387. http://dx.doi.org/10.1021/la903149y

[24] H. Niu, Q. Yang, K. Tang and Y. Xie, "Large-Scale Synthesis of Single-Crystalline MgO with Bone-Like Nanostructures," Journal of Nanoparticle Research, Vol. 8, No. 6, 2006, pp. 881-888.

[25] F. Meshkani and M. Rezaei, "Facile Synthesis of Nanocrystalline Magnesium Oxide with High Surface Area," Powder Technology, Vol. 196, No. 1, 2009, pp. 85-88. http://dx.doi.org/10.1016/j.powtec.2009.07.010

[26] F. Meshkani and M. Rezaei, "Effect of Process Parameters on the Synthesis of Nanocrystalline Magnesium Oxide with High Surface Area and Plate-Like Shape by Surfactant Assisted Precipitation Method," Powder Technology, Vol. 199, No. 2, 2010, pp. 144-148. 
http://dx.doi.org/10.1016/j.powtec.2009.12.014

[27] L.-Z. Pei, L. Z. Yin, J. F. Wang, J. Chen, C. G. Fan and Q. F. Zhang, "Low Temperature Synthesis of Magnesium Oxide and Spinel Powders by a Sol-Gel Process," Journal of Materials Research, Vol. 13, No. 3, 2010, pp. 339-343. http://dx.doi.org/10.1590/S1516-14392010000300010

[28] M. F. Parveen, S. Umapathy, V. Dhanalakshmi and R. Anbarasan, "Synthesis and Characterization of Nanosized $\mathrm{Mg}(\mathrm{OH})_{2}$ and Its Nanocomposite with Poly(Vinyl Alcohol)," NANO: Brief Reports and Reviews, Vol. 4, No. 3, 2009, pp. 147-156.

[29] M. Rezaei, M. Khajenoori and B. Nematollahi, "Synthesis of High Surface Area Nanocrystalline $\mathrm{MgO}$ by Pluronic P123 Triblock Copolymer Surfactant," Powder Technology, Vol. 205, No. 1-3, 2011, pp. 112-116. http://dx.doi.org/10.1016/j.powtec.2010.09.001

[30] C. Chizallet, G. Costentin, H. Lauron-Pernot, M. Che, C. Bonhomme, J. Maquet, F. Delbecq and P. Sautet, "Study of the Structure of $\mathrm{OH}$ Groups on $\mathrm{MgO}$ by $1 \mathrm{~d}$ and $2 \mathrm{~d}{ }^{1} \mathrm{H}$ MAS NMR Combined with DFT Cluster Calculations," The Journal of Physical Chemistry C, Vol. 111, No. 49, 2007, pp. 18279-18287. http://dx.doi.org/10.1021/jp077089g

[31] Y. V. Larichev, B. L. Moroz, V. I. Zaikovskii, S. M. Yunusov, E. S. Kalyuzhnaya, V. B. Shur and V. I. Bukhtiyarov, "XPS and TEM Studies on the Role of the Support and Alkali Promoter in $\mathrm{Ru} / \mathrm{MgO}$ and $\mathrm{Ru}-\mathrm{Cs} / \mathrm{MgO}$ Catalysts for Ammonia Synthesis," The Journal of Physical Chemistry C, Vol. 111, No. 26, 2007, pp. 9427-9436. http://dx.doi.org/10.1021/jp066970b

[32] M. B. Kasture, P. Patel, A. A. Prabhune, C. V. Ramana, A. A. Kulkarni and B. L. V. Prasad, "Synthesis of Silver Nanoparticles by Sophorolipids: Effect of Temperature and Sophorolipid Structure on the Size of Particles," Journal of Chemical Sciences, Vol. 120, No. 6, 2008, pp. 515-520. http://dx.doi.org/10.1007/s12039-008-0080-6

[33] J. Lv, L. Qiu and B. Qu, "Controlled Growth of Three Morphological Structures of Magnesium Hydroxide Nanoparticles by Wet Precipitation Method," Journal of Crystal Growth, Vol. 267, No. 3-4, 2004, pp. 676-684. http://dx.doi.org/10.1016/j.jcrysgro.2004.04.034

[34] K. Mageshwari and R. Sathyamoorthy, "Studies on Photocatalytic Performance of $\mathrm{MgO}$ Nanoparticles Prepared by Wet Chemical Method," Transactions of the Indian Institute of Metals, Vol. 65, No. 1, 2012, pp. 49-55. http://dx.doi.org/10.1007/s12666-011-0106-5

[35] M. A. Boudreau, J. F. Fisher and S. Mobashery, "Messenger Functions of the Bacterial Cell Wall-Derived Muropeptides," Biochemistry, Vol. 51, No. 14, 2012, pp. 2974-2990. http://dx.doi.org/10.1021/bi300174x

[36] A. Panacek, L. Kvitek, R. Prucek, M. Kolar, R. Vecerova, N. Pizurova, V. K. Sharma, T. J. Nevecna and R. Zboril, "Silver Colloid Nanoparticles: Synthesis, Characterization, and Their Antibacterial Activity," The Journal of Physical Chemistry B, Vol. 110, No. 33, 2006, pp. 1624816253. http://dx.doi.org/10.1021/jp063826h

[37] X. Pan, Y. Wang, Z. Chen, D. Pan, Y. Cheng, Z. Liu, Z. Lin and $X$. Guan, "Investigation of Antibacterial Activity and Related Mechanism of a Series of Nano- $\mathrm{Mg}(\mathrm{OH})_{2}$," ACS Applied Materials \& Interfaces, Vol. 5, No. 3, 2013, pp. 1137-1142. http://dx.doi.org/10.1021/am302910q

[38] K. Rishnamoorthy, J. Y. Moon, H. B, Hyun, S. K. Cho and S.-J. Kim, "Mechanistic Investigation on the Toxicity of $\mathrm{MgO}$ Nanoparticles toward Cancer Cells," Journal of Materials Chemistry, Vol. 22, No. 47, 2012, pp. 2461024617. http://dx.doi.org/10.1039/c2jm35087d 